\title{
INFORMATION CAPACITY DATABASE IN THE RATING MODEL ON THE BASIS OF POLISH AND ITALIAN REAL ESTATE MARKETS
}

\author{
Małgorzata Renigier-Biłozor, PhD \\ Faculty of Geodesy, Geospatial and Civil Engineering \\ University of Warmia and Mazury in Olsztyn \\ e-mail: malgorzata.renigier@uwm.edu.pl \\ Andrzej Biłozor, PhD \\ Faculty of Geodesy, Geospatial and Civil Engineering \\ University of Warmia and Mazury in Olsztyn \\ e-mail:abilozor@uwm.edu.pl
}

\begin{abstract}
Preliminary data analyses in decision-making systems and procedures are very important for numerous reasons, in particular because the accumulation and analysis of large data sets is costly and time-consuming. The effective use of decision support systems, including on the real estate market, requires the elimination of noise. The authors have proposed to eliminate redundant data with the use of the modified method for evaluating the capacity of the data set, which is applied in the process of classifying the condition of real estate markets. The proposed procedure (subsystem) is an attempt to improve the effectiveness of analyses relating to the development of methods for rating real estate markets. The proposed solutions will be simulated on the example of leading real estate markets in Poland and Italy.
\end{abstract}

Key words: decision-making systems, highest integral information capacity, real estate market rating.

JEL Classification: B41, C10, D80, R31.

Citation: Renigier-Biłozor, M., Biłozor A., 2016, Information Capacity Database in the Rating Model on the Basis of Polish and Italian Real Estate Markets, Real Estate Management and Valuation, vol. 24, no. 3, pp. 40-51.

DOI: $10.1515 /$ remav-2016-0020

\section{Introduction}

Making decisions is an integral element of human life, and the most frequent activity performed on a micro- and macro-scale. Decisions are made by analyzing information that is available for a given problem and selecting the best alternative for further action. RAO (1994) quotes SAMUEL BUTLER, who said: "Life is the art of drawing sufficient conclusions from insufficient premises", to indicate that decisionmaking involves uncertainty and the risk of error. In theory, every decision has a $50 \%$ chance of success and $50 \%$ chance of failure. It could, therefore, be argued that a mistake could be avoided 100\% if no decisions were made. This, however, withholds development. Many decision-makers face such an alternative when they are charged with responsibility for their actions and the resulting consequences. In line with the Chinese saying: "To guess is cheap, to guess wrongly is very expensive", efforts should be made to maximize the probability of the most appropriate decision being made. Making optimum decisions should rely on reliable data describing reality, in line with the decisionmaker's preferences (SAATY 2008). However, access to reliable data or information is difficult nowadays, not so much because of lack of access to them, but due to excessive amounts of such data (so-called information noise) and difficulties in the proper selection of the right type of data.

The authors have proposed to use Hellwig's method in the process of eliminating redundant data 
and maximizing the capacity of the analyzed data set. The heuristic method proposed by HELLWIG (1976) takes into account both class-feature correlation and correlation between pairs of variables. The best subset of features is selected from among all possible subsets, which maximizes the so-called "integral capacity of information". Therefore, the results lead to obtaining the necessary set of features that contain essential information describing the situation on the local real estate market. The proposed procedure is part of a decision support system within the framework of developing a methodology for real estate market rating.

The study was prepared as a result of implementing a research project No.UMO-2014/13/B/HS4/ 00171 financed from the funds of the National Science Centre.

\section{Literature review}

The objective of the decision theory (STONER and WANKEL 1994) is to provide detailed information for the decision-making process. Mathematical, statistical and scientific methods are used to forecast changes in the environment, as well as to predict and evaluate multivariate outcomes of actions. The effectiveness of the decision-making process is determined by the availability of sufficient quantities of high-quality information relating to endogenous and exogenous aspects of the analyzed problem, an adequate level of competence exhibited by decision-makers and supporting personnel (subcontractors), and appropriate technical as well as financial resources (computers, databases) and decision-support tools (dedicated decision-support systems) (RENIGIER-BIŁOZOR 2013, SŁOWIŃSKI 1992, WANG 2005). According to KNOSALA (2005), the decision-making process should aim to objectivize the decision by eliminating subjective factors.

Comprehensive information is rarely available on the real estate market, and most decisions are made under uncertainty. By identifying the degree of uncertainty, we can develop methods that limit, control and account for uncertainty in the decision-making process (RAO 1994). For this reason, market analyses require solutions and methods that reflect reality, as well as account for and, most importantly, minimize the degree of uncertainty. The above implies that market participants conduct transactions without mutual knowledge which leads to asymmetry in the decision-making process. This could lower the efficiency and, consequently, the effectiveness of the entire market. On account of the multi-faceted nature and multiplicity of factors determining the final result of the decision-making process in the real property market, it is possible to offer assistance by working out a certain system in the form of a multi-stage classification structure which could ensure smooth and widespread access to reliable and precise information.

Decision support systems, by definition, should aid in and strengthen decision processes. These are computer-based systems that compile information from a variety of sources, assist in the organization and analysis of information, and facilitate the evaluation of assumptions underlying the use of specific models (SUSTAINABLE DEVELOPMENT...2015, p. 398). Many decision support systems for the analysis of real estate have been developed worldwide: BIM-based decision-support system for master planning of sustainable largescale developments (KIM et al. 2015), geographic information systems, i.e. a GISbased decision support tool to quantitatively assess land-use suitability (WANG et al. 2013), a decisionmaking model in progress management of urban development (LI et al. 2009), multi-criteria decision aids for the management of complex knowledge in planning for sustainable development (KAIN, SÖDERBERG 2008), group decision support for public policy planning (GROENENDAAL 2003), or public participation in a spatial decision support system for public housing (BARTON et al. 2005). Moreover, KAKLAUSKAS et al. (2015) claim that decision support system should comprise of the following four major constituent parts: data (database and its management system), models (model base and its management system), a user interface, and a message management system. The definition, collection, development and adjustment of databases pose some of the greatest challenges.

The main problem involves the selection and application of appropriate features which are relevant to the specificity of information connected with the real estate market and create a kind of coherent system aiding the decision-making process. The scarcity of relevant information results from the shortcomings of market effectiveness analyses (CASE AND SHILLER 1989, FAMA 1990, GROSSMAN AND STIGLITZ 1980, DAWIDOWICZ et al. 2014). According to CASE and SHILleR (1989, 1990), the ineffectiveness of the analyzed market can be attributed to individual investors who do not have access to objective knowledge about the real estate market.

The construction of decision rules, or classifiers, is closely connected with the problem of selecting 
features, i.e. the number of explanatory (independent) variables. As emphasized by FARAWAY (2002), HASTIE et al. (2008) and MADDALA (2008), redundant attributes, as well as attributes which have no connection to the phenomena under consideration, increase the cost of the decision-making process. Moreover, introducing useless and superfluous information (noise) causes a loss in the degrees of freedom, which makes interpretation more difficult and influences its quality. Several classification methods have been proposed in literature, the main types being: wrapped methods, embedded methods, and filter methods. The simplest approach to feature selection is represented by ranking methods, also called filters (OLVERA-LÓPEZ et al. 2010). These methods require an index (some coefficient) specifying the quality of each according to the assumed criterion. GARCIA et al. (2012) emphasize that the advantages of the method are: universality - the obtained subset of features is independent of the classifier, an algorithm of this type can be used for every classification problem, and speed - as we are independent of the classification method, the computational complexity does not affect the speed and efficiency of this algorithm. Disadvantages include the need for the estimation of multivariate probability distributions and the lack of taking into account the relationships between features, as well as the possible lack of stability. Another type of selection is based on the search for the feature subsets, called wrappers, where the assessment of the feature subsets is usually done by some classification model. According to ARNAIZ-GONZÁLEZ et al. (2016) and ReUNANEN (2005) the advantages of this method are: the chosen subset of features is suited to the requirements or specific nature of the decision algorithm, a better accuracy is obtained than in the case of filter methods, and it is universal - an algorithm of this type can be used for any classification problem. As the drawbacks, the aforementioned authors indicate greater computational complexity. The embedded methods are a group of algorithms that utilize certain characteristics of learning algorithms and perform automated selection at the learning (training) stage of the decision algorithm (DEVIJVER and KITTLER 1982). The advantages of these methods include speed and accuracy (NAVIN et al. 2005); they are designed for a specific algorithm. One of their drawbacks is the lack of universality, as these methods can be applied to only one algorithm.

As part of this study, the authors have proposed a rating system for real estate markets as a decision support system applicable to the property market. At the same time, however, a rating measure of the real estate markets should provide general and clear information classifying the object of analysis. Considering the above, the main task of this study and classification of the market (rating) was the reduction of the number of variables in the decision-making process, but the main aim was to reduce the possibilities of decision-making choices, and thus minimizing the risk of wrong decisions. Every decision support system relies on databases, and the results of all analyses and evaluations are influenced mainly by the quality and reliability of data. The authors assumed that this can be achieved by developing a procedure that leads to obtaining the necessary set of features that constitute essential information describing the situation on the local real estate market. The authors have proposed to use Hellwig's method in the process of eliminating redundant data and maximizing the capacity of the analyzed data set. In terms of classification methods, the procedure for feature selection developed by the author can be considered to be a combination of the ranking and wrapped methods, together with searching, because it uses both of these types of methods, where the number of selected features is optimized by a decision algorithm, in this case by sensitivity analysis based on the maximum value of the information capacity coefficient for each variable, considered as the minimum input threshold for the set of selected data.

\section{Data and methods}

The solutions proposed by authors are the next step in real estate market rating methodology development. A rating system for the real estate market is a modern tool for diagnosing the condition and potential of the market, and for supporting market participants in the decision-making process. Since the main purpose of a rating is to provide quick, objective, reliable and updated information, a dataset has to be developed as a platform for quantitative and qualitative analyses.

The determination of the rating score for the real estate markets was prepared in the form of a procedure (RENIGIER-BIEOZOR 2015) aimed at obtaining a significant element supporting decisionmaking in the market (scheme No. 1). The author proposed the methodology of the rating score in the form of a multivariate procedure. The procedure consisted of the several stages that are methodologically open and could constitute a separate decision-making subsystem. 


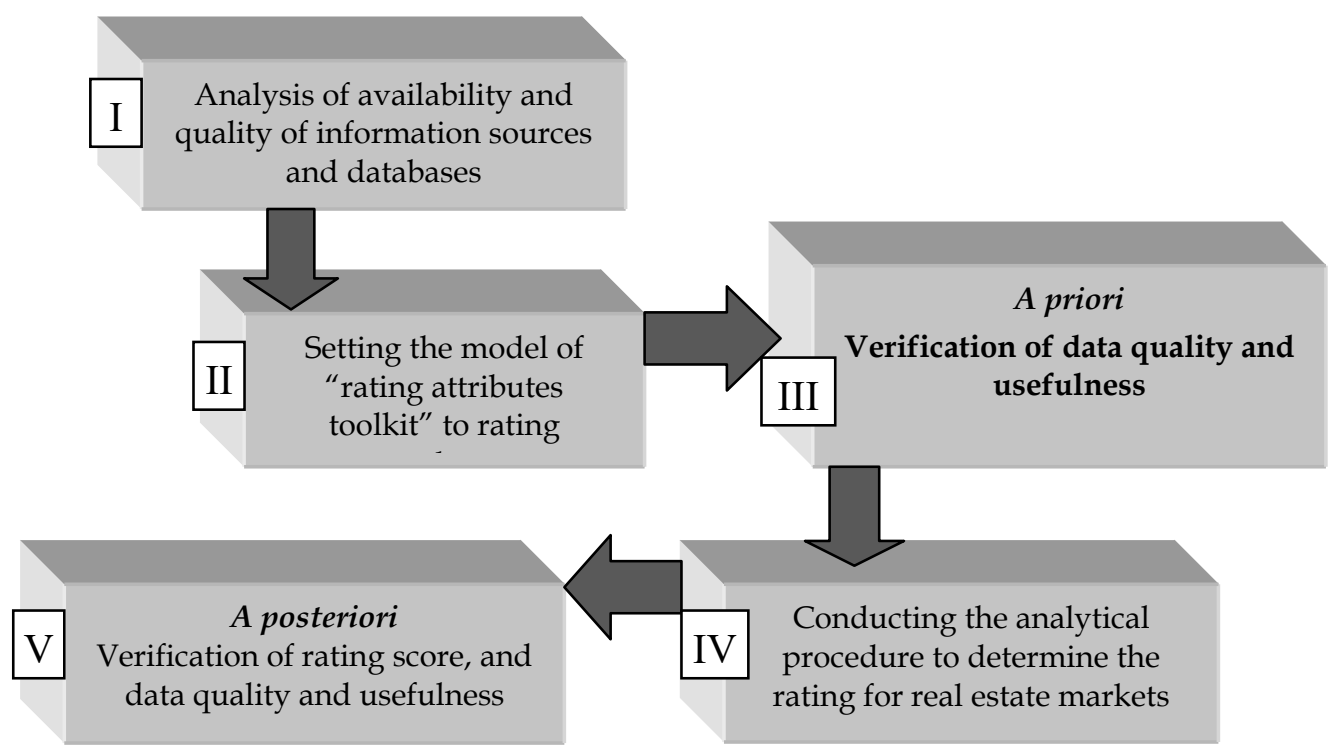

Scheme 1. Procedure for establishing the rating score of real estate markets. Source: Authors' own elaboration.

In this study, the databases for real estate market ranking were verified a priori as part of a procedure aiming to identify significant elements that support decision-making on the market (scheme no. 2).
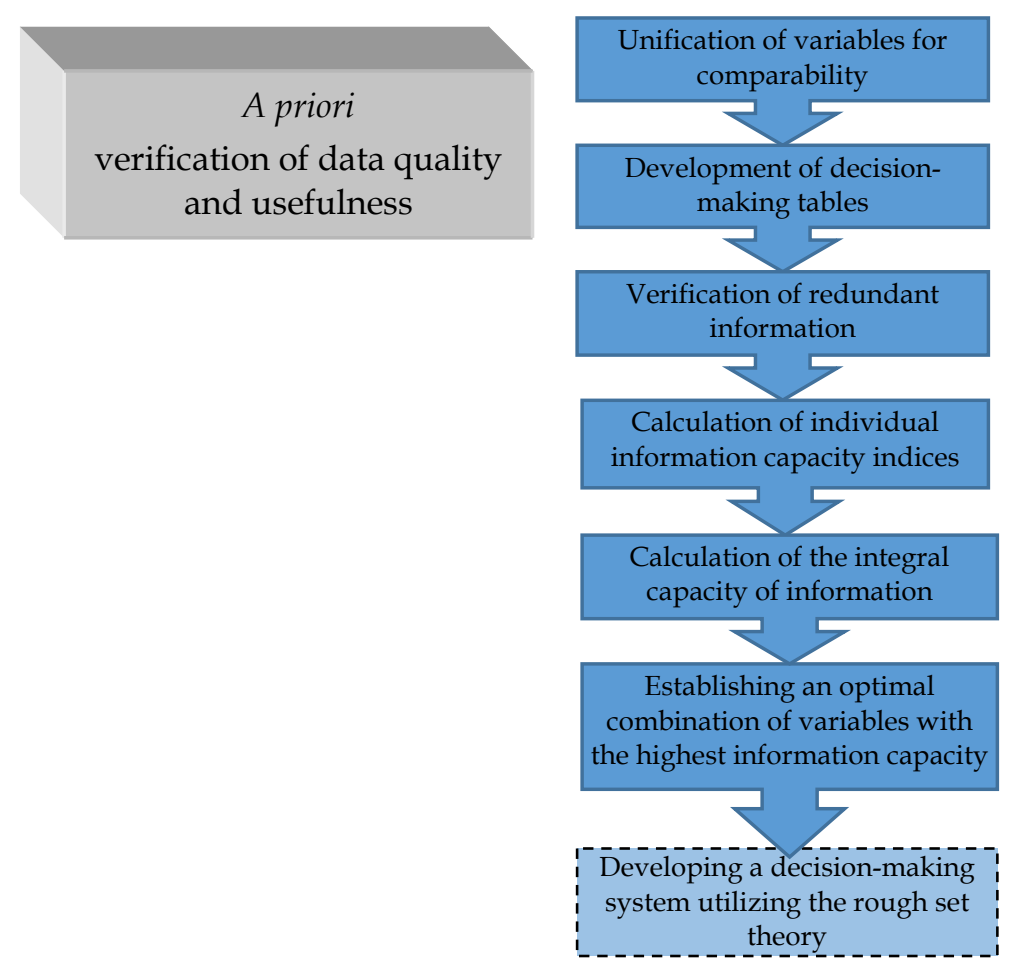

Scheme 2. A priori verification of the database in the form of a decision-making sub-system. Source: Authors' own elaboration.

The data in Figure 1 indicate that an a priori verification should be the next step after identifying the type of the analyzed market and data collection - development of the rating toolkit (see RENIGIERBIŁOZOR et al. 2014, 2015). 


\subsection{Scope of data analysis}

Leading property markets in Poland and Italy were analyzed to verify research assumptions and for the simulation of results (Fig. 1). The study was conducted based on 2014 data for 16 Polish and 18 Italian markets. The data was collected for residential real estate markets represented by residential apartments, taking into account the commonness of their use. All markets are the capitals of their regions, constituting the most important space of impact onto other regions and the best point of reference - representation of their region; also on account of more complete access to data.
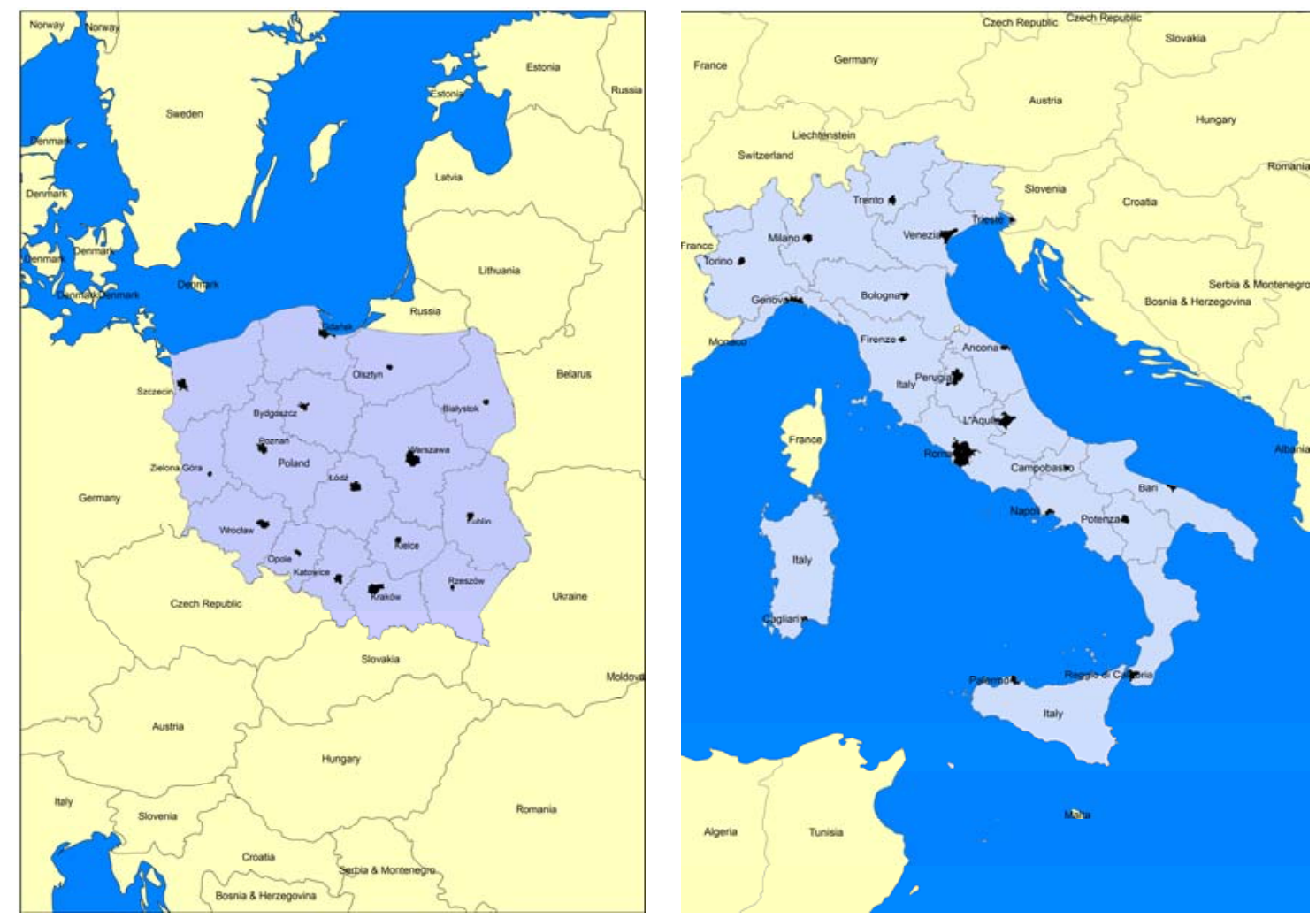

Fig. 1. The area of real estate market analysis for Poland and Italy. Source: Authors' own elaboration using ArcGis.

The databases were developed based on the following sources of data: for Poland - the National Bank of Poland, Central Statistical Office, local data bank, Polish Bank Association, AMRON SARFIN reports, Local government rankings published by the Rzeczpospolita daily and the Przekrój magazine, for Italy - the National Bank of Italy, ISTAT (National Institute Of Statistics, Italy), Agenzia delle entrate (Database of real estate prices), Agenzia del territorio, and local government rankings.

The following indicators were used in the databases:

IND. 1 - average salary in PLN (for Italy $1 €=4.0014$ PLN for 2014)

IND. 2 - ranking of the quality of life based on the "quality of the local government" (max 100p)

IND. 3 - number of deaths for population over the age of 50 (per 1,000 residents)

IND. 4 - age structure of potential clients (25-45 population group vs. total population in a given area), (percent.)

IND. 5 - fuel prices per liter

IND. 6 - number of new registered businesses in industry and construction (per 10,000 residents)

IND. 7 - local government spending on public utilities and environmental protection (per resident)

IND. 8 - number of apartments (per 1,000 residents)

IND. 9 - usable dwelling space (per resident)

IND. 10 - average number of rooms in a dwelling

IND. 11 - total number of issued construction permits (per 10,000 residents)

IND. 12 - number of issued construction permits - individual (per 10,000 residents)

IND. 13 - the average floor area of a room $\left(\right.$ per $\left.\mathrm{m}^{2}\right)$

IND. 14 - number of developers on the local market (per 10,000 residents) 
IND. 15 - number of real estate transactions (per 10,000 residents)

IND. 16 - value of real estate transactions (per 1,000 residents)

IND. 17 - affordability of rental housing (number of square meters that can be financed from an average local salary per month)

IND. 18 - number of real estate offers (per 1,000 residents)

IND. 19 - ranking of quality of life based health ( $\max 100$ p.)

IND. 20 - ranking of quality of life based on satisfaction with life (max 100 p.)

IND. 21 - ranking of quality of life based on safety (max 100 p.)

IND. 22 - unemployment rate (per cent)

IND. 23 - unemployment rate (per cent average from last 5 years)

IND. 24 - difference between regional and local unemployment rate (per cent)

IND. 25 - population growth (per 1,000 residents)

IND. 26 - net migration rate (per 1,000 residents)

IND. 27 - number of marriages (per 1,000 residents)

IND. 28 - number of students (per 1,000 residents)

IND. 29 - contribution of individuals in the productive age (per cent)

IND. 30 - contribution of individuals in the pre-productive age group (per cent)

IND. 31 - contribution of individuals in the post-productive age (per cent)

IND. 32 - number of sports clubs (per 10,000 residents)

IND. 33 - number of cultural centers (per 100,000 residents)

IND. 34 - number of new businesses (per 1,000 residents)

IND. 35 - number of self-employed individuals (per 1,000 residents)

IND. 36 - number of businesses employing 0-9 workers (per 10,000 individuals in the productive age)

IND. 37 - number of businesses employing 10-49 workers (per 10,000 individuals in the productive age)

IND. 38 - number of businesses employing 50-249 workers (per 10,000 individuals in the productive age)

IND. 39 - number of businesses employing 250 or more workers (per 10,000 individuals in the productive age )

IND. 40 - Gross Domestic Product (Poland=100p.)

IND. 41 - local government spending (per resident)

IND. 42 - difference between the national average salary and the average salary on the local market (per cent)

IND. 43 - the average number of individuals in an apartment

IND. 44 - availability of apartments on the primary market based on average salary $\left(\mathrm{m}^{2}\right)$

IND. 45 - availability of apartments on the secondary market based on average salary $\left(\mathrm{m}^{2}\right)$

IND. 46 - offered purchasing power on the local housing market (average salary on the local market/average price per $1 \mathrm{~m}^{2}$ of property on the local market)

IND. 47 - transaction purchasing power on the local housing market (average salary on the local market /average price per $1 \mathrm{~m}^{2}$ of property on the local market)

IND. 48 - availability of mortgages in terms of $\mathrm{m}^{2}$ (average property price / average credit rating of a family or individual)

IND. 49 - availability of mortgages on the secondary market in PLN loans $\left(\mathrm{m}^{2}\right)$

IND. 50 - availability of mortgages on the primary market in PLN loans $\left(\mathrm{m}^{2}\right)$

IND. 51 - number of real estate agents on the local market (per 10,000 residents)

IND. 52 - number of real estate appraisers on the local market (per 10,000 residents)

IND. 53 - affordability of rental housing on the secondary market (number of square meters that can be financed from an average local salary per month)

IND. 54 - difference between the average offered price and average transaction price of $1 \mathrm{~m}^{2}$ of real estate on the primary market (PLN)

IND. 55 - difference between the average offered price and average transaction price of $1 \mathrm{~m}^{2}$ real estate on the secondary market (PLN)

IND. 56 - changes in local property offer prices (per cent)

IND. 57 - average time on the secondary market (in days)

IND. 58 - difference between minimum and maximum transaction prices on the primary market 
$\left(\mathrm{PLN} / \mathrm{m}^{2}\right)$

IND. 59 - difference between minimum and maximum transaction prices on the secondary market $\left(\mathrm{PLN} / \mathrm{m}^{2}\right)$

IND. 60 - population density $\left(\right.$ per $\left.\mathrm{km}^{2}\right)$

\section{Empirical results}

In the following stage, the database was verified to remove redundant information. According to the authors, this stage could constitute an independent subsystem of the data support system for defining the influence of attributes on property prices and the condition of real estate markets. For this reason, the module was expanded to include procedures that support decision-making on the real estate market. The correlations between variables were determined, and a decision table was developed. In this case, the most important step involves the identification of the decision variable which will be used to verify the significance of the dataset. In this study, the decision variable is the average property price, which can provide information about the sufficiency of the database in the proposed market ranking method. In this procedure, any other variable can act as the decision variable, depending on the purpose of the analysis. The remaining variables were identified as conditional variables.

The presence of redundant information was verified by correlation analysis and Student's t-test (Appendix 1). Variables characterized by correlation coefficients higher than 0.90 but lower correlations with property prices were deleted (marked as "del." in Appendix 1). The analysis indicates that, for Polish markets, the following indicators were removed: 4, 15, 18, 22, 34, 35, 38, 43, 44, 47 and 50, while for the Italian markets: 2, 4, 6, 14, 23, 36, 38, 46, 48, 50, 55 and 59.

The next step of the proposed procedure includes the development of individual indices of information capacity according to the Hellwig method. On this basis, individual indices of information capacity were determined for each combination according to the following formula:

$$
h_{k j}=\frac{r_{j}^{2}}{1+\sum_{\substack{j=1 \\ j, j}}^{m}\left|r_{i j}\right|}
$$

rj - correlation between $Y$ and $X j$,

rij - correlation between $X i$ and $X j$,

$k \quad$ - number of combinations, $\mathrm{k}=1,2, \ldots \ldots \ldots, 1$,

$j \quad$ - variable number of combinations, $\mathrm{j}=1,2, \ldots \ldots, \mathrm{m}$.

Finally, integral information capacity indices should be determined for each combination according to the following formula:

$$
H_{k}=\sum_{j=1}^{m} h_{k j}, t=1,2, \ldots,
$$

The optimal set of information results from a combination of variables with the highest $H k$. The authors modified the classical assumptions of this theory and conducted the sensitivity analysis in order to increase the efficiency of the analysis and the time saved. In this analysis, the influence of every variable on the result of the integral information capacity (Hi) was verified. The total integral information capacity $(\mathrm{Ht})$ (with all variables) was compared with individual integral information capacity (Hi) (after deleting each variable) respectively. Those deleted variables with individual indicators larger then the total indicator were removed (bold font - Tab. 1 and Appendix 2). The analysis indicated that the remaining variables constituted a combination of the optimal set with the highest integral information capacity (Ho) (Tab. 1).

The analysis indicated that, for Polish markets, the combination of the optimal set of indicators with the highest information capacity are as follows (Tab. 1): usable dwelling space, value of real estate transactions, affordability of rental housing, ranking of the quality of life based on health, ranking of quality of life based on satisfaction with life, unemployment rate, net migration rate, number of sports clubs, number of businesses employing 0-9 workers, number of businesses employing 250 or more workers, Gross Domestic Product, local government spending, availability of apartments on the secondary market based on average salary, offered purchasing power on the local 
housing market, number of real estate agents on the local market, difference between the average offered and average transaction price of $1 \mathrm{~m}^{2}$ of real estate on the secondary market, average time on the secondary market, difference between the minimum and maximum transaction prices on the primary market, difference between the minimum and maximum transaction prices on the secondary market and population density.

Table 1

Indices of information capacity

\begin{tabular}{|c|c|c|c|c|c|}
\hline \multicolumn{3}{|c|}{ Polish markets } & \multicolumn{3}{|c|}{ Italian markets } \\
\hline & Sets of variable combinations & $\begin{array}{l}\text { Indicator of } \\
\text { integral } \\
\text { information } \\
\text { capacity }(\mathrm{H})\end{array}$ & & Sets of variable combinations & $\begin{array}{c}\text { Indicator of } \\
\text { integral } \\
\text { information } \\
\text { capacity }(\mathrm{H})\end{array}$ \\
\hline$(\mathrm{Ht})$ & 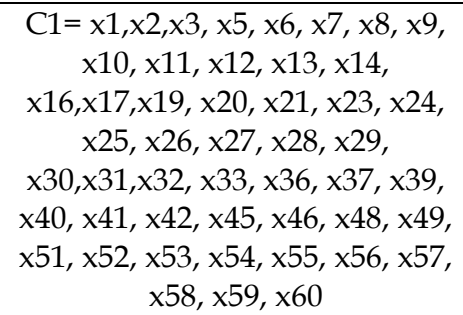 & 0.6889 & $(\mathrm{Ht})$ & 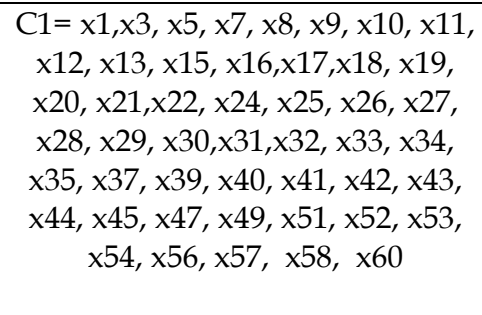 & 0.5989 \\
\hline Hi (x1) & $\begin{array}{c}\mathrm{C} 2=x 2, x 3, x 5, x 6, x 7, x 8, x 9, \\
x 10, x 11, x 12, x 13, x 14, \\
x 16, x 17, x 19, x 20, x 21, x 23, x 24, \\
x 25, x 26, x 27, x 28, x 29, \\
x 30, x 31, x 32, x 33, x 36, x 37, x 39, \\
x 40, x 41, x 42, x 45, x 46, x 48, x 49, \\
x 51, x 52, x 53, x 54, x 55, x 56, x 57, \\
x 58, x 59, x 60\end{array}$ & 0.6900 & $\mathrm{Hi}(x 1)$ & 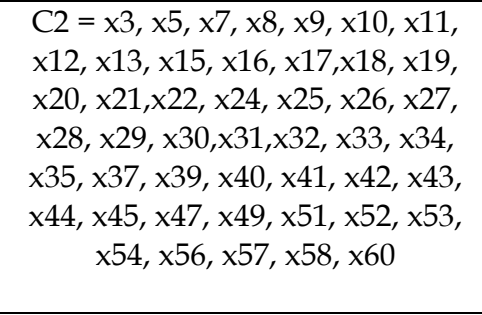 & 0.5989 \\
\hline $\mathrm{Hi}(\mathrm{x} 2)$ & 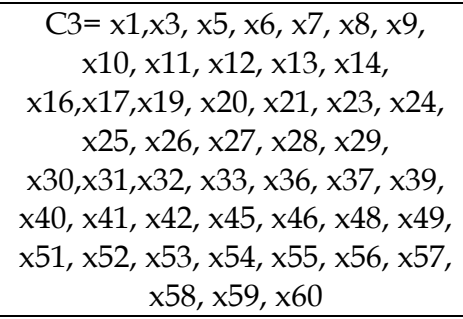 & 0.6953 & $\mathrm{Hi}(\mathrm{x3})$ & 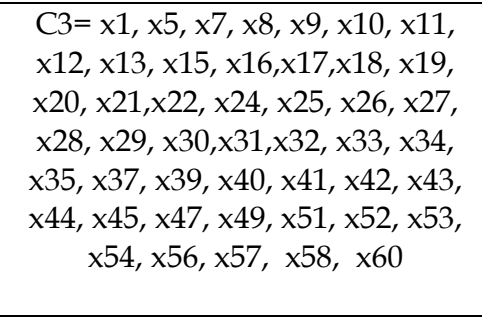 & 0.6028 \\
\hline $\mathrm{Hi}(\mathrm{x} 3)$ & C4= etc. & 0.7001 & $\mathrm{Hi}(\mathbf{x} 5)$ & C4=etc. & 0.6017 \\
\hline Ho & $\begin{array}{l}\text { C61 }=\times 9, \times 16 \times 17 \times 19 \times 20 \times 23 \\
\times 26 \times 32 \times 36 \times 39 \times 40 \times 41 \times 45 \times 46 \\
\times 51 \times 55 \times 57 \times 58 \times 59 \times 60\end{array}$ & 0.9374 & Ho & $\begin{array}{l}\mathrm{C} 61=x 1, \times 7, \times 11, \times 15, \times 16, x 17, \\
x 18, \times 25, \times 33, x 40, x 44, x 45, \times 49, \\
x 56, x 57, \times 58\end{array}$ & 0.9071 \\
\hline
\end{tabular}

Source: own calculation.

In the case of Italian markets, the sets of indicators are as follows: average salary in PLN, local government spending on public utilities and environmental protection, total number of issued construction permits, number of real estate transactions, value of real estate transactions, affordability of rental housing, number of property offers, population growth, number of cultural centers, Gross Domestic Product, availability of apartments on the primary market in terms of average salary, availability of apartments on the secondary market based on average salary, availability of mortgages on the secondary market in PLN loans, changes in local property offer prices, average time on the secondary market, and the difference between the minimum and maximum transaction prices on the primary market.

The last step of the mentioned procedure involves developing a decision-making procedure on the basis of the rough set theory. In this case, the cause-and-effect relationship is assumed on the Boolean sum and if-then rule. The identified variables, which form a dataset with maximum information capacity, will constitute the core of the system and will be used as input data for developing decision rules. The vast set of variables will be reduced and optimized to increase the effectiveness and reliability of decision rules based on the rough set theory. This step of the procedure will be discussed in an upcoming paper. 


\section{Discussion and conclusions}

One from the most important reasons behind undertaking research in this area is the problems which occurs in advanced real estate analysis connected with the collection of appropriate features of the real estate market and the development of a dataset. Within the scope of the study, the authors develop a procedure in the form of a decision-making support system, making use of Hellwig's method of integral capacity of information.

The goal of the feature selection in the proposed solution is the reduction of the dimension of the input vector through the identification of a feature (variable) subset that describes the object in the best way and guarantees the highest model quality, in this case the highest information capacity obtained from the searching algorithm where we perform a forward selection of the " $\mathrm{i}$ " new features and next remove the " $\mathrm{j}$ " least useful ones from the result. It is well-known that there are no ideal selection methods, but the solution posited by the authors has high potential for application. It is quick and easy to compute. Moreover, in contrast to filter methods, the proposed combination of various types of selection takes into account the relationships between features, because the method optimizes the set on the basis of finding the maximal correlation with the outcome (dependent, explained) variable and the minimal correlation with other classifiers. It is also characterized by the clarity and simplicity of result interpretation. The simplicity of the proposed method is important for the end users of the developed decision algorithms, who, even without mathematical training, can sufficiently comprehend the ideas on which the presented method is based. The method also has possible disadvantages, among which one can point out the assumption of linear dependency between the analyzed variables, an increase in the complexity of analysis when a large number of variables are considered, and the possible occurrence of instability.

The results of the analysis indicated the set of features that constitute essential information describing the situation on the, separately analyzed, Polish and Italian property markets. The following indicators, which are common for both markets, were selected to maximize the range of information describing the analyzed markets: value of real estate transactions, affordability of rental housing, Gross Domestic Product, availability of apartments on the secondary market based on the average salary, average time on the secondary market and the difference between the minimum and maximum transaction prices on the primary market, with $\mathrm{Ho}=0.8746$ for the Polish example and $\mathrm{Ho}=0.8569$ for its Italian counterpart.

The proposed solution is a part of the rating methodology of real estate markets related to the means and procedures of designating classifications of real property markets. The necessity of determining classifications of real property markets results from various needs connected with becoming acquainted with and analyzing market mechanisms. The classification of the real property market's potential on the basis of the conditions and specific character of the analyzed urban space allows not only for its evaluation, but also for influencing development and adjustment to current and future needs.

\section{References}

Arnaiz-González Á., Blachnik M., Kordos M., García-Osorio C., 2016. Fusion of Instance Selection Nethods in Regression Tasks. Information Fusion Volume 30, July 2016, pp. 69-79

Barton, J.; Plume, J.; Parolin, B. 2005. Public Participation in a Spatial Decision Support System for Public Housing, Computers, Environment and Urban Systems 29(6): 630-652.

Case, K. E., Shiller, R. J., 1989, The Efficiency of the Market for Single-Family Homes. American Economic Review, 79(1), 125-137. (DOI): http://dx.doi.org/10.3386/w2506

Case, K. E., Shiller, R. J., 1990, Forecasting Prices and Excess Returns in the Housing Market. Real Estate Economics, 18(3), 253-273. http://dx.doi.org/10.1111/1540-6229.00521

Dawidowicz A., Renigier-Biłozor M, , Radzewicz A., 2014, An algorithm for the purposes of determining the real estate markets efficiency in Land Administration System. Survey Review. Volume 46, Issue 336 (May 2014), pp. 189-204. DOI: http://dx.doi.org/10.1179/1752270613Y.0000000080

Fama E., 1990, Efficient Capital Markets: II, Journal of Finance, 46 (5) 1990, pp. 1575-1617 http://dx.doi.org/10.2307/2328565

Faraway J.J. (2002), Practical Regression and Anova using R, http://cran.rproject.

org/doc/contrib/Faraway-PRA.pdf (dostęp: 04.04.2016).

Garcia S., Derrac J., Cano J.R., Herrera F.2012. Prototype Selection for Nearest Neighbor Classification: 
Taxonomy and Empirical Study IEEE Trans. Pattern Anal. Mach. Intell., 34 (3) (2012), pp. 417-435

Grossman S. J., Stiglitz J. E. (1980). On the Impossibility of Informationally Efficient Markets. American Economic Review. 70, pp. 393-408.

Hastie T., Tibshirani R., Friedman J., 2008. The Elements of Statistical Learning. Data Mining, Inference, and Prediction, Springer Science+Business Media B.V., New York.

Hellwig Z., 1976, Przechodniość relacji skorelowania zmiennych losowych i płynące stąd wnioski ekonometryczne (Transitivity of Correlation and some Econometric Implications) (in Polish), Przegląd Statystyczny, 23, 1, 1976, pp. 65-83.

Kain, J.-H.; Söderberg, H. 2008. Management of Complex Knowledge in Planning for Sustainable Development: The Use of Multi-Criteria Decision Aids, Environmental Impact Assessment Review 28(1): 7-21.

Kim, J. I.; Kim, J.; Fischer, M.; Orr, R. 2015. BIM-based Decision-Support Method for Master Planning of Sustainable Large-Scale Developments, Automation in Construction 58: 95-108.

Knosala E., 2005, Zarys nauki administracji [Outline of administrative science]. Kantor wydawniczy, Zakamycze

Li, W.; Su, Z.-Y.; Chen, M. 2009. Applications of Decision-making Model in Progress Management of Urban Development, Systems Engineering - Theory \& Practice 29(3): 34-39.

Maddala G.S. , 2008. Ekonometria [Econometric], Wydawnictwo Naukowe PWN, Warszawa.

Navin Lal T., Chapelle O., Elisseeff A.2005. Embedded Methods. Feature Extraction, Foundations and Applications. Springer, 2005

Olvera-López J.A., Carrasco-Ochoa J.A., Martínez-Trinidad J.F., Kittler J. 2010. A Review of Instance Selection Methods. Artif. Intell. Rev., 34 (2) (2010), pp. 133-143

Rao C. R., 1994, Statystyka i prawda (Statistics and the truth) (in Polish). PWN Warszawa

Renigier-Biłozor M., 2013, Structure of a Decision Support Subsystem in Real Estate Management. Folia Oeconomica Stetinensia. Vol. 13, issue 1. 13 (21) 2013/1 pp. 56-75 10 pt. http:/ / dx.doi.org/10.2478/foli-2013-0007.

Renigier-Biłozor M., Wiśniewski R., Biłozor A., Kaklauskas A., 2014, Rating Methodology for Real Estate Markets - Poland Case Study. International Journal of strategic property management. Vol. 18. Issue 2 pp. 198-212 ISNN. 1648-715X http://dx.doi.org/10.3846/1648715X.2014.927401

Renigier-Biłozor M., Biłozor A, Wiśniewski R., 2015, Rating Attributes Toolkit for the Residential Property Market. Under review.

Renigier-Biłozor M., 2015, Rating Scoring System for Property Market. Under review.

Reunanen J., 2005. Search Strategies for Wrapper Methods. Feature Extraction, Foundations and Applications. Springer, 2005.

Saaty T. L., 2008, Decision-Making with the Analytic Hierarchy Process, J. Services Sciences. Vol. 1.No. 1.

Słowiński R., 1992, Intelligent Decision Support. Handbook of Applications and Advances of the Rough Sets Theory. Kluwer Academic Publishers, Dordrecht.

Stoner J. A. F., Wankel Ch., 1994, Kierowanie (Management) (in Polish). Państwowe Wydawnictwo Ekonomiczne. Warszawa

Sustainable Development of Real Estate. 2015. editor. Kaklauskas A. , Zavadskas K., Dargis R. , Bardauskiene D., monograph. Vilnius. ISBN 978-609-457-842-7, eISBN 978-609-457-841-0, doi:10.3846/2336-M

Wang W.K., 2005, A Knowledge-Based Decision Support System for Measuring the Performance of Government Real Estate Investment. Expert Systems with Applications 29 (2005) pp. 901-912

Wang, H.; Shen, Q.; Tang, B.-S.; Skitmore, M. 2013. An Integrated Approach to Supporting Land-Use Decisions in Site Redevelopment for Urban Renewal in Hong Kong, Habitat International 38: 70-80

Van Groenendaal, W. J. H. 2003. Group Decision Support for Public Policy Planning, Information $\mathcal{E}$ Management 40(5): 371-380. Devijver P., Kittler J., Pattern Recognition: A Statistical Approach. Englewood Clifs, Londyn, Prentice-Hall 1982.

Appendix 1

Results of removing variables on the basis of correlation analysis

\begin{tabular}{|c|c|c|c|c|c|c|c|}
\hline \multicolumn{4}{|c|}{ Polish markets } & \multicolumn{4}{|c|}{ Italian markets } \\
\hline $\begin{array}{l}\text { No. of } \\
\text { indic. }\end{array}$ & $\begin{array}{l}\text { Correlat. } \\
\text { coefficient }\end{array}$ & $\begin{array}{l}\text { Correlat. } \\
\text { coefficient }\end{array}$ & $\begin{array}{l}\text { Significance } \\
\text { of correlation }\end{array}$ & $\begin{array}{l}\text { No. of } \\
\text { indicator }\end{array}$ & $\begin{array}{l}\text { Correlat. } \\
\text { coefficient }\end{array}$ & $\begin{array}{l}\text { Correlat. } \\
\text { coefficient }\end{array}$ & $\begin{array}{l}\text { Significance } \\
\text { of correlation }\end{array}$ \\
\hline
\end{tabular}




\begin{tabular}{|c|c|c|c|c|c|c|c|c|c|}
\hline & & & $\begin{array}{l}\text { with } \\
\text { price }\end{array}$ & $\begin{array}{l}\text { results on the } \\
\text { basis of } \\
\text { Student's } t- \\
\text { test for } \\
t \text { crit. }=2,14\end{array}$ & & & & $\begin{array}{l}\text { with } \\
\text { price }\end{array}$ & $\begin{array}{l}\text { results on the } \\
\text { basis of } \\
\text { Student's t- } \\
\text { test for } \\
\text { crit. }=2.10\end{array}$ \\
\hline & 8 & -0.97 & 0.61 & 15.81 & $x$ & 2 & 0.93 & 0.31 & \\
\hline del. $^{*}$ & 43 & & -0.57 & & $x$ & 4 & & 0.32 & 9.74 \\
\hline \multirow[t]{2}{*}{ del. } & 4 & 0.96 & -0.24 & 9.91 & del. & 2 & 0.92 & 0.31 & \\
\hline & 29 & & -0.29 & & & 29 & & 0.32 & 9.73 \\
\hline \multirow[t]{2}{*}{ del. } & 15 & 0.91 & 0.42 & 7.99 & $x$ & 4 & 0.91 & & \\
\hline & 16 & & 0.71 & & $x$ & 20 & & & \\
\hline \multirow[t]{2}{*}{ del. } & 18 & 0.92 & 0.83 & 8.75 & del. & 4 & 0.98 & 0.30 & 28.23 \\
\hline & 19 & & 0.84 & & & 29 & & 0.32 & \\
\hline$x^{*}$ & 18 & 0.92 & 0.83 & 8.86 & del. & 6 & 0.95 & -0.29 & 11.62 \\
\hline$x$ & 40 & & 0.80 & & & 35 & & -0.30 & \\
\hline \multirow[t]{2}{*}{ del. } & 22 & 0.99 & -0.57 & 2.69 & $x$ & 6 & 0.95 & -0.29 & 12.30 \\
\hline & 23 & & -0.61 & & $x$ & 36 & & -0.19 & \\
\hline$x$ & 34 & 0.95 & 0.73 & 12.11 & & 35 & 0.98 & -0.30 & 19.88 \\
\hline$x$ & 35 & & 0.64 & & del. & 36 & & -0.19 & \\
\hline \multirow[t]{2}{*}{ del. } & 34 & 0.99 & 0.73 & 52.51 & del. & 14 & 0.96 & 0.56 & 13.85 \\
\hline & 36 & & 0.74 & & & 15 & & 0.62 & \\
\hline \multirow[t]{2}{*}{ del. } & 35 & 0.95 & 0.64 & 11.84 & & 21 & 0.90 & -0.33 & 8.06 \\
\hline & 36 & & 0.74 & & del. & 23 & & -0.19 & \\
\hline \multirow[t]{2}{*}{ del. } & 38 & 0.93 & 0.54 & 9.83 & $\mathrm{x}$ & 22 & 0.99 & -0.20 & 28.00 \\
\hline & 39 & & 0.65 & & $x$ & 23 & & -0.19 & \\
\hline \multirow[t]{2}{*}{ del. } & 44 & 0.95 & -0.44 & 11.01 & del. & 38 & 0.91 & 0.31 & 8.63 \\
\hline & 45 & & -0.56 & & & 511 & & 0.44 & \\
\hline$x$ & 44 & 0.91 & -0.44 & 8.08 & & 44 & 0.96 & -0.83 & 13.50 \\
\hline$x$ & 47 & & -066 & & del. & 46 & & -0.79 & \\
\hline$x$ & 44 & 0.93 & -0.44 & 9.36 & del. & 48 & 0.98 & 0.96 & 18.23 \\
\hline$x$ & 49 & & -0.17 & & & 49 & & 0.97 & \\
\hline$x$ & 44 & 0.90 & -0.44 & 7.88 & $x$ & 48 & 0.98 & 0.96 & 21.25 \\
\hline$x$ & 50 & & -0.05 & & $x$ & 50 & & 0.97 & \\
\hline$x$ & 45 & 0.96 & -0.56 & 12.45 & & 49 & 0.92 & 0.97 & 9.41 \\
\hline \multirow[t]{2}{*}{$x$} & 47 & & -0.66 & & del. & 50 & & 0.92 & \\
\hline & 46 & 0.96 & -0.76 & 12.81 & del. & 55 & 0.97 & 0.70 & 18.15 \\
\hline \multirow[t]{2}{*}{ del. } & 47 & & -0.66 & & & 56 & & 0.71 & \\
\hline & 49 & 0.94 & -0.17 & 10.84 & & 58 & 0.99 & 0.87 & 23.17 \\
\hline del. & 50 & & -0.05 & & del. & 59 & & 0.83 & \\
\hline
\end{tabular}

*del. - variables removed; $\mathrm{x}$ - analysis exluded

Source: own calculation.

Appendix 2

Influence of every variable on the result of the integral information capacity

\begin{tabular}{|c|c|c|c|}
\hline \multicolumn{2}{|c|}{ Polish markets } & \multicolumn{2}{|c|}{ Italian markets } \\
\hline $\begin{array}{c}\text { Sets of } \\
\text { variables }\end{array}$ & $\begin{array}{c}\text { Indicate of integral } \\
\text { information capacity }(\mathrm{H})\end{array}$ & $\begin{array}{c}\text { Sets of } \\
\text { variables }\end{array}$ & $\begin{array}{c}\text { Indicate of integral } \\
\text { information capacity }(\mathrm{H})\end{array}$ \\
\hline$(\mathrm{Ht})$ & 0.6889 & $(\mathrm{Ht})$ & 0.5989 \\
\hline Hi (x1) & 0.6900 & Hi (x1) & 0.5989 \\
\hline $\mathrm{Hi}(\mathrm{x} 2)$ & 0.6953 & $\mathrm{Hi}(\mathrm{x} 3)$ & 0.6028 \\
\hline Hi(x3) & 0.7001 & $\mathrm{Hi}(\times 5)$ & 0.6017 \\
\hline $\mathrm{Hi}(\mathrm{x} 5)$ & 0.6941 & $\mathrm{Hi}(\mathrm{x} 7)$ & 0.5972 \\
\hline $\mathrm{Hi}(\mathrm{x} 6)$ & 0.6959 & $\mathrm{Hi}(\mathbf{x} 8)$ & 0.6066 \\
\hline $\mathrm{Hi}(\mathrm{x} 7)$ & 0.6949 & Hi(x9) & 0.6073 \\
\hline $\mathrm{Hi}(\mathbf{x} 8)$ & 0.6899 & Hi(x10) & 0.6014 \\
\hline $\mathrm{Hi}(\mathrm{x} 9)$ & 0.6881 & $\mathrm{Hi}(\mathrm{x} 11)$ & 0.5930 \\
\hline Hi(x10) & 0.6925 & $\mathrm{Hi}(\mathbf{x 1 2})$ & 0.6015 \\
\hline Hi(x11) & 0.6908 & $\mathrm{Hi}(\mathbf{x 1 3})$ & 0.6047 \\
\hline
\end{tabular}




\begin{tabular}{|c|c|c|c|}
\hline Hi(x12) & 0.6967 & $\mathrm{Hi}(\mathrm{x} 15)$ & 0.5980 \\
\hline $\mathrm{Hi}(\mathrm{x13})$ & 0.6976 & $\mathrm{Hi}(\mathrm{x} 16)$ & 0.5822 \\
\hline Hi(x14) & 0.6954 & $\mathrm{Hi}(\mathrm{x} 17)$ & 0.5885 \\
\hline $\mathrm{Hi}(x 16)$ & 0.6788 & $\mathrm{Hi}(\mathrm{x} 18)$ & 0.5984 \\
\hline $\mathrm{Hi}(\mathrm{x} 17)$ & 0.6698 & $\mathrm{Hi}(\mathbf{x 1 9 )}$ & 0.6053 \\
\hline $\mathrm{Hi}(x 19)$ & 0.6730 & $\mathrm{Hi}(\mathrm{x} 20)$ & 0.6065 \\
\hline $\mathrm{Hi}(\mathrm{x} 20)$ & 0.6889 & $\mathrm{Hi}(\mathrm{x} 21)$ & 0.6065 \\
\hline $\mathrm{Hi}(\times 21)$ & 0.6988 & $\mathrm{Hi}(\mathrm{x} 22)$ & 0.6100 \\
\hline $\mathrm{Hi}(\mathrm{x} 23)$ & 0.6847 & $\mathrm{Hi}(\mathrm{x} 24)$ & 0.6044 \\
\hline $\mathrm{Hi}(\times 24)$ & 0.6950 & $\mathrm{Hi}(\mathrm{x} 25)$ & 0.5947 \\
\hline $\mathrm{Hi}(\times 25)$ & 0.6943 & $\mathrm{Hi}(\mathrm{x} 26)$ & 0.6006 \\
\hline $\mathrm{Hi}(x 26)$ & 0.6818 & $\mathrm{Hi}(\mathrm{x} 27)$ & 0.6114 \\
\hline $\mathrm{Hi}(\times 27)$ & 0.6910 & $\mathrm{Hi}(\mathrm{x} 28)$ & 0.6049 \\
\hline $\mathrm{Hi}(\times 28)$ & 0.6912 & $\mathrm{Hi}(\times 29)$ & 0.6068 \\
\hline Hi(x29) & 0.6954 & $\mathrm{Hi}(\mathbf{x} 30)$ & 0.6099 \\
\hline $\mathrm{Hi}(\mathrm{x30})$ & 0.6985 & $\mathrm{Hi}(\mathrm{x} 31)$ & 0.6005 \\
\hline Hi(x31) & 0.6986 & $\mathrm{Hi}(\mathbf{x 3 2})$ & 0.6074 \\
\hline $\mathrm{Hi}(\mathrm{x} 32)$ & 0.6789 & $\mathrm{Hi}(\times 33)$ & 0.5996 \\
\hline $\mathrm{Hi}(\mathrm{x} 33)$ & 0.6969 & $\mathrm{Hi}(\mathrm{x} 34)$ & 0.6041 \\
\hline $\mathrm{Hi}(\mathrm{x} 36)$ & 0.6803 & $\mathrm{Hi}(x 35)$ & 0.6056 \\
\hline Hi(x37) & 0.6907 & $\mathrm{Hi}(\times 37)$ & 0.6093 \\
\hline $\mathrm{Hi}(\times 39)$ & 0.6824 & $\mathrm{Hi}(x 39)$ & 0.6022 \\
\hline $\mathrm{Hi}(x 40)$ & 0.6761 & $\mathrm{Hi}(x 40)$ & 0.5902 \\
\hline $\mathrm{Hi}(x 41)$ & 0.6826 & $\mathrm{Hi}(x 41)$ & 0.6013 \\
\hline $\mathrm{Hi}(\mathrm{x} 42)$ & 0.6896 & $\mathrm{Hi}(\mathrm{x} 42)$ & 0.6032 \\
\hline $\mathrm{Hi}(x 45)$ & 0.6812 & $\mathrm{Hi}(\mathrm{x} 43)$ & 0.6115 \\
\hline $\mathrm{Hi}(x 46)$ & 0.6617 & $\mathrm{Hi}(x 44)$ & 0.5790 \\
\hline $\mathrm{Hi}(x 48)$ & 0.6904 & $\mathrm{Hi}(x 45)$ & 0.5857 \\
\hline Hi(x49) & 0.6987 & $\mathrm{Hi}(x 47)$ & 0.6035 \\
\hline $\mathrm{Hi}(x 51)$ & 0.6854 & $\mathrm{Hi}(x 49)$ & 0.5695 \\
\hline Hi(x52) & 0.6961 & $\mathrm{Hi}(\times 51)$ & 0.6009 \\
\hline Hi(x53) & 0.6905 & $\mathrm{Hi}(\times 52)$ & 0.6062 \\
\hline Hi(x54) & 0.6941 & $\mathrm{Hi}(\mathbf{x} 53)$ & 0.6044 \\
\hline $\mathrm{Hi}(\times 55)$ & 0.6778 & $\mathrm{Hi}(\mathbf{x} 54)$ & 0.6052 \\
\hline Hi(x56) & 0.6936 & $\mathrm{Hi}(x 56)$ & 0.5789 \\
\hline $\mathrm{Hi}(\times 57)$ & 0.6691 & $\mathrm{Hi}(\mathrm{x} 57)$ & 0.5881 \\
\hline $\mathrm{Hi}(\times 58)$ & 0.6817 & $\mathrm{Hi}(\mathrm{x} 58)$ & 0.5799 \\
\hline $\mathrm{Hi}(\times 59)$ & 0.6882 & $\mathrm{Hi}(\times 60)$ & 0.6039 \\
\hline $\mathrm{Hi}(x 60)$ & 0.6843 & & \\
\hline
\end{tabular}

Source: own calculation. 